\title{
How MIT Helped Cultivate Generations of Entrepreneurs
}

\author{
Edward Roberts (Massachusetts Institute of Technology) \\ Daniel Forbes (University of Minnesota)
}

KEYWORDS: Entrepreneurship, Startups, Higher Education.

The Massachusetts Institute of Technology is known around the world as a center of learning and knowledge creation. But what is less well-known is the central role the university has played in advancing the practice of entrepreneurship.

Prof. Ed Roberts of MIT tells the story of his institution's entrepreneurial contributions in his forthcoming book, "Celebrating Entrepreneurs: How MIT Nurtured Pioneering Entrepreneurs Who Built Great Companies." Roberts, an EIX contributor (https://eiexchange.com/content/284-how-strategy-and-i ndustry-should-shape-your-

choi?search=Edward\%20Roberts) , recently shared with us some highlights from the book and its lessons for entrepreneurs, universities and policymakers.

More information about the book is available at the website

CelebratingEntrepreneurs.com (http://celebratingentrepreneurs.com) . The site provides for direct purchase from Amazon at discounted prices for the electronic and paperback versions. Professor Roberts will be donating his proceeds from the book to endowment funds that help support MIT's entrepreneurship programs.

\section{EIX: What is this book about?}

ROBERTS: The first half of the book focuses upon our half-century history of creating from scratch what we lovingly call the "MIT Entrepreneurial Ecosystem." The ideas and programs from that ecosystem have dramatically impacted the U.S. and have spread globally, primarily through university collaborations by us and our former faculty and $\mathrm{PhD}$ recipients.

The second half of the book contains four chapters that tell the stories of the pioneering MIT entrepreneurs themselves. These are the people who formed and built the life sciences and biotechnology industries, the Internet, the CAD-CAM and robotics industries and even "modern finance." The final chapter highlights recent interviews and company histories that include others from the software, electronics and other industries, and diverse founding teams from around the developing world.

\section{EIX: What prompted you to write this book?}

ROBERTS: I had two very different motivations. First, I wanted to document for history all of the people whose efforts led to the dramatic changes in MIT's culture and to the internal organizations that have made entrepreneurship the most widespread interest of students and faculty alike, across the entire MIT campus. They deserved to be remembered and credited for their bold ideas and hard work over many years. And by doing this, I could create an evidence-based set of examples that could help other universities, regions and countries adopt entrepreneurial pathways toward significant economic growth and well-being.

Second, I believe we have learned much from those great entrepreneurs, whom I describe and quote directly, about the challenges faced even by firms that eventually become huge successes. It doesn't just "happen," but critical events and strategies repeatedly arise in the life of new companies. And I wanted to communicate those experiences in the words of the many founders cited throughout the book, so as to share credibly their problems and solutions.

\section{EIX: What kinds of readers would benefit from the book?}

ROBERTS: Anyone interested in the history and practice of entrepreneurship will gain a deeper understanding of the kinds of things universities can do as critical parts of their ecosystems, both regionally and globally. 
University faculty and staff will learn from our experiences as they undertake their own efforts to build major entrepreneurship programs at their own universities. In addition, the second half of the book provides dozens of examples and case studies of entrepreneurs who started and built highly successful firms, and these can be useful in class teachings and as the bases for broadening the samples here into larger focused research studies.

\section{EIX: Would you share with us an example of one of the companies built by MIT alumni, and how MIT helped in the company's creation?}

ROBERTS: Every company's story is a different one. I'll try two very different examples: Akamai Technologies and Flagship Ventures, which later became Flagship Pioneering.

Akamai is a technology services company that helps companies - like retailers, banks, and others - do business more efficiently and more securely. The founding and growth of Akamai happened because of several things: a brilliant Math Department PhD student, cross-campus collaboration of both graduate and undergraduate students, a devoted professor and the incentive of a $\$ 50 \mathrm{~K}$ Business Plan Competition. The brilliant student, Danny Lewin, had a personal financial problem that needed solving. Danny was a Technion (of Israel) alumnus, married with two children and doing great theoretical work with Professor Tom Leighton. But he felt desperate because he was approaching bankruptcy, with large student debts from himself and his kids. Danny was having a beer with his MIT dorm neighbor, Preetish Nijhawan from the MIT Sloan School, who came up with a solution. "Let's turn your great ideas for coping with Internet 'hotspots' into an entrant in the MIT $\$ 50,000$ Business Plan competition. If we win, you can take all of the prize and pay off your debts," Preetish generously offered.

They approached Danny's professor, Tom Leighton, a pure theoretician, to join their team, which he reluctantly did solely because of his real enthusiasm for Danny. While they did NOT win the $\$ 50,000$ prize (note: today's prize is worth $\$ 100,000$ ), they got lots of experience and attention from many others. The launch of Akamai Technologies involved long efforts, many MIT students working for nothing on this intriguing Math Department project, and trying one after another approach to move the idea into practice. The technology proved itself when only the Akamai system didn't crash during the postSuper Bowl Victoria's Secret fashion show that featured supermodels in lingerie! The company grew rapidly after that, now carrying one-third of the world's Internet traffic. But it suffered a devastating crisis when Danny Lewin became the first person killed by terrorists aboard the American Airlines flight from Boston to New York that kicked off the $9 / 11$ disaster.

\section{EIX: Tell us about Flagship Ventures.}

ROBERTS: This is a company where personal contacts made at MIT were instrumental to the founding process. Noubar Afeyan was near-completion of his PhD work with Professor Danny Wang, who led the new BioTechnology Processing Lab. Noubar decided to get a small dose of entrepreneurship education before leaving MIT and came to see me to get into my limitedenrollment "Corporate Entrepreneurship" class. I rejected him because I thought he lacked the practical knowledge to be able to do the demanding project at the subject's end-phase. He returned one week later, having read the entire course syllabus, and argued strongly for admission. I told him that he would likely flunk the course but l'd admit him based solely on his obviously high motivation. I ended up giving him an $\mathrm{A}+$ and told him he had done the best job of all $80 \mathrm{grad}$ students in the class. That began a relationship that has lasted more than 30 years.

While working part-time for Professor Wang as the Industrial Transfer post-doc of the lab, Noubar returned three months after graduation with a draft business plan for his first startup, PerSeptive BioSystems, his new idea for biotech manufacturing equipment. To get going, Noubar had received small angel investments from his father and from Professor Wang. After a few months, and many changes to his proposal, my co-founders of Zero Stage Capital became his first real investors. Fortunately, Noubar was very successful in building that company, had an IPO, then sold the firm to a large Connecticut instrument manufacturer. Noubar led that large company's entry into biotechnology, and made lots of money for them and himself. He returned to Boston and became co-founder/CEO of a unique biotech venture creation and investment firm, then called Flagship Ventures and now named Flagship Pioneering, which among its achievements became the largest investor in Massachusetts companies. Flagship has spawned a massive number of new biotech firms -including Moderna, which has just received a 
government pledge of $\$ 500$ million to aid its development of a drug to prevent coronavirus.

\section{EIX: There's a great deal of interest in} entrepreneurial ecosystems nowadays the social, political, economic and cultural elements that influence whether a region becomes a center for entrepreneurship. What can people outside of universities, such as policymakers or businesspeople, do to take advantage of what universities have to offer their ecosystems?

ROBERTS: First, they should read the first half of my book! Next, they should attempt to start local task forces or oversight organizations that bring together people and organizations that can strengthen the ecosystem. These might include: representatives of their own entrepreneurial communities, however small; a university that is preferably technology-based or at least technology-inclusive; a local source of venture capital (either private or public); a government agency that is committed to economic growth; and a large industrial firm that would hope to generate more local jobs and attract suppliers and partner firms. That group would encourage collaborative efforts to advance the policy objectives of entrepreneurship-based growth and development. We have institutionalized that approach with our own MIT REAP (Regional Entrepreneurial Acceleration Program), that accepts about eight different regions of the world into a two-year relationship that includes opportunities for their (and our) learning and cooperation. Our decade-long experiences with REAP is discussed in Chapter 7 of the book, along with a number of other single-country efforts we have undertaken around the world. 